Du Pont sets

\section{up new lab, others to come}

\section{Washington}

Reluctant to commit themselves to the commercial promise of the "new biology" only a few years ago, the United States chemical giants are now queuing up to jump in the deep end. Last week the largest of all, Du Pont, announced plans for a new $\$ 85$ million life sciences complex, designed for 700 scientists and technical personnel, to be built near the company's headquarters in Wilmington, Delaware.

One of Du Pont's closest rivals, Monsanto, has already established what the company describes as a "free-standing molecular biology center', which will have "a larger component of basic research than at most industrial companies". According to Monsanto chairman, Mr John Hanley, genetic engineering is likely to become a major branch of the company in the future; "we're up to the eyeballs in molecular biology", he says.

Both companies already have substantial contracts with outside research institutions. Last month, for example, Du Pont announced a five-year, \$6 million agreement with Harvard Medical School (see Nature 16 July, p. 191) to conduct research on molecular genetics, with the company receiving exclusive licences to market any resulting products. Monsanto signed a similar deal with the same institution, though with a slightly different focus, six years ago; recently it has been working with Genentech on bovine and porcine hormones, looking at ways of producing more meat with less feed.

At the same time, however, major chemical companies such as Du Pont and Monsanto are building up their in-house capacity at a rate which is already producing major recruitment difficulties.

Du Pont's life sciences complex is part of a plan to raise from 10 to 20 per cent the proportion of gross revenues which the company earns from sales of pharmaceutical, biomedical and agricultural products. According to the company's new chairman, Mr Edward Jefferson, it intends to spend 21 per cent of its $\$ 570$ million research budget next year on the life sciences, and that figure is expected to increase over the next five years.

The new complex will include a 250,000-square-foot facility for health sciences research and a 100,000-squarefoot expansion of existing plant laboratories at the company's experimental station in Delaware. Completion is

scheduled for December 1983, and the company intends to expand the scope of current research not only in molecular genetics, but also in fields such as immunology, neurobiology, cardiology, gerontology, plant biology, plant pathology and entomology.

Du Pont's announcement seems to have been partly precipitated by rumours that the company's current attempts to take over the oil company Conoco could interfere with Du Pont's recent moves to diversify away from petroleum-based products. Mr Jefferson has denied such rumours, claiming that the company intends to continue its aggressive thrust into the life sciences for their own sakeand for the profit they may bring.

Several petroleum companies are themselves beginning to enter the fields. Atlantic Richfield has set up a genetic engineering laboratory which company officials describe as "our most academic laboratory"; novel arrangements being discussed include two-year research appointments, and lengthy sabbaticals for research workers who wish to spend time at universities.

Waiting in the wings is the Exxon Research and Engineering Company, the research wing of Exxon Corporation, with an annual research budget of $\$ 489$ million - almost half that of the National Science Foundation. Company officials declined

\title{
Research council plans academic rescue
}

Britain's Science and Engineering Research Council is to come to the aid of outstanding academics threatened with redundancy as a result of cuts in the universities' income. Last week, the council decided that it would help academics in departments marked for closure to transfer to other universities, and would pay their salaries for up to ten years if necessary. The council is calculating that the universities should then have reorganized themselves and that the University Grants Committee should be able to take up the bill again.

The council is particularly anxious that good individuals and groups should not be lost simply because they happen to work in those universities faced with the largest cuts in their income. It will be looking for academics that it considers especially valuable who are about to lose their jobs and may also consider setting up special transfer fellowships for which threatened academics will be eligible to apply.

As yet, the council has little idea of how many individuals it will want to support or how much money it should set aside. Estimates will have to wait at least until the autumn, according to Sir Geoffrey Allen, chairman of the council, when universities have a better idea of where economies will fall. In the meantime, the council has increased the number of replacement to comment last week on the company's plans, saying that no announcement was expected for several months; however, there are rumours that Exxon is working on an arrangement that it likes to compare with the position of the Bell Laboratories in telecommunications research.

The broad potential impact of life sciences research in medicine is revealed in a report, entitled Forecast of Emerging Technologies, soon to be released by the Food and Drug Administration, of a study in which 190 experts both inside and independent of the agency were asked to predict which new medical technologies were likely to emerge within the next fifteen years.

Almost a quarter of the 168 technologies listed involved basic areas of genetic engineering and computer technology. Eight technologies accounted for one-third of the citations, headed by hybridoma technology, nuclear magnetic resonance imaging and the use of recombinant DNA to produce interferon.

Meanwhile at least one university has decided to provide financial support tc faculty members attempting to exploit the result of their research in molecular biology. The Michigan State University Foundation has announced that it is contributing $\$ 100,000$ to help set up a new company, called Neogen, which is expected to specialize in the genetic engineering of plants.

David Dickson

fellowships, by which a senior academic returns to research leaving a tenured post for a younger person, from 15 to 20 per year. The council, which will pay the net cost for five years, expects to spend $£ 500,000$ a year on the scheme.

Sir Geoffrey's main concern is that the cuts in university income will further undermine the dual support system for research, whereby the University Grants Committee provides funds for staff and well equipped laboratories and the research councils award grants for specific projects. The gradual undermining of the universities' income over recent years has already weakened the research base, according to Sir Geoffrey, who is anxious that the restructuring of the unviersity system caused by the cuts should be designed to strengthen the research base to near its former level rather than weaken it further.

He would like to see individual universities concentrate their efforts to a greater extent than implied by the University Grants Committee in its advice to them, preferring a smaller but stronger research base to a larger, weaker one. Although those views are shared by the University Grants Committee, which has attempted to confine the misery caused by the cuts by being selective, Sir Geoffrey believes that the selectivity could and should go further.

Judy Redfearn 